\title{
Physico-chemical and microbiological assay of the Lázaro beach in Ubatuba-SP.
}

\author{
Anderson Luís Sabino, Débora Poleis Maciel, Cláudia de Moura, Danilo Balthazar-Silva, Ana Beatriz Carollo \\ Rocha-Lima.
}

\begin{abstract}
Lázaro beach is located in the city of Ubatuba, north coast of São Paulo, and it is frequented by many families during the summer for having few waves, shallow sea and easy access. Its surroundings have vacation homes, marinas and bars/kiosks and there are several streams that cross the sands and flow into the sea. This study evaluated the physicochemical parameters $(\mathrm{pH}$, orthophosphate, turbidity, nitrate, nitrite, ammoniacal nitrogen and dissolved oxygen) and microbiological parameters (Escherichia coli) of the sea of the Lázaro beach and the microbiological parameters of one of these streams. For this, we used the reagent kit Ecokit II ${ }^{\circledR}$ and Colipaper $\AA$. The values obtained for the parameter nitrate were in high concentration compared to the limit established for salt water intended for primary contact recreation (Class 1 of CONAMA Resolution 357/2005) and the microbiological evaluation of the stream showed high count of coliforms $(7.840 \mathrm{CFU} / 100 \mathrm{ml})$. So, the results demonstrate evidence of contamination caused by discharges of urban effluents into the stream that flows into the sea, which may be affecting the water quality and also can be a threat to the tourist's health. This results corroborates with official monitoring, in which about $20 \%$ of the results attesting impropriety to the use of the Lázaro beach in the year of this evaluation (2017).
\end{abstract}

\section{Key words:}

Environmental Analysis, Water Resources, Coliforms.

\section{Introduction}

Lázaro beach is located in the city of Ubatuba, north coast of São Paulo, and it is frequented by many families during the summer for having few waves, shallow sea and easy access ${ }^{1,2}$. Its surroundings have vacation homes, marinas and bars/kiosks and there are several streams that cross the sands and flow into the sea. This study evaluated the physico-chemical parameters $(\mathrm{pH}$, orthophosphate, turbidity, nitrate, nitrite, ammoniacal nitrogen and dissolved oxygen) and microbiological parameters (Escherichia coli) of the sea of the Lázaro beach and the microbiological parameters of one of these streams. For this, we used the reagent kit Ecokit $I \cong$ and Colipaper®. The evaluation was carried out in May 2017.

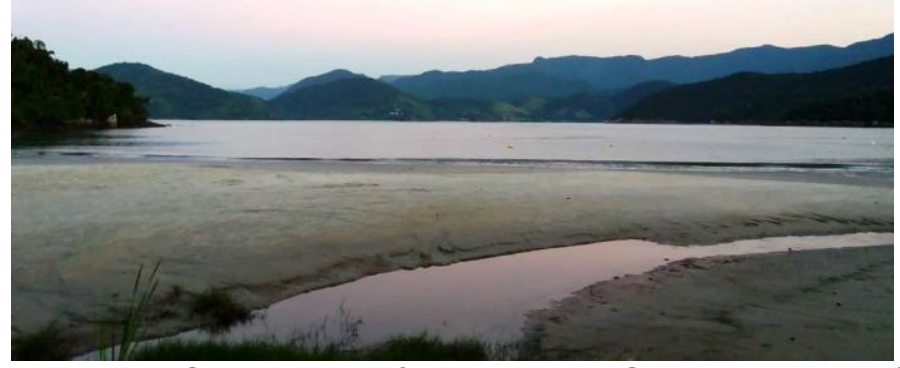

Image 1. Stream on Lázaro beach. Source: Moura, C. (2018)

\section{Results and Discussion}

The values obtained for the parameter nitrate were in high concentration compared to the limit established for salt water intended for primary contact recreation (Class 1 of CONAMA Resolution 357/2005) and the microbiological evaluation of the stream showed high count of coliforms.
Chart 1. Main physico-chemical and microbiological results.

\begin{tabular}{|c|c|c|}
\hline Parameters & $\begin{array}{c}\text { CONAMA Resolution } \\
\mathbf{3 5 7 / 2 0 0 5} \text { (Class 1) }\end{array}$ & $\begin{array}{c}\text { Values } \\
\text { obtained }\end{array}$ \\
\hline Nitrate & $>0,4 \mathrm{mg} / \mathrm{L} \mathrm{N}$ & $0,7 \mathrm{mg} / \mathrm{L} \mathrm{N}$ \\
\hline $\begin{array}{c}\text { Thermotolerant } \\
\text { coliforms (stream) }\end{array}$ & -- & $\begin{array}{c}7.840 \\
\mathrm{CFU} / 100 \mathrm{ml}\end{array}$ \\
\hline
\end{tabular}

These results demonstrate evidence of contamination caused by discharges of urban effluents into the stream that flows into the sea, which may be affecting the water quality and also can be a threat to the tourist's health. In Ubatuba, only $39 \%$ of the properties have sewage collection $^{3}$. This results corroborates with official monitoring, in which about $20 \%$ of the results attesting impropriety to the use of the Lázaro beach in the year of this evaluation ${ }^{4}$.

\section{Conclusions}

At the time of great tourist demand, the Lázaro beach suffers further contamination by sewage, what affects the water quality and also can be a threat to the tourist's health.

\footnotetext{
Guia de Destinos (C) 2008-2018. Ubatuba: praia do Lázaro https://guia.melhoresdestinos.com.br/praia-do-lazaro-230-6304-l.html.

Accessed on June 20, 2019.

${ }^{2}$ Leite, F. 5 praias do litoral norte de São Paulo para ir com crianças. Viagem e Turismo 27 oct 2017. https://viagemeturismo.abril.com.br/blog/brasis/5 praias-do-litoral-norte-de-sao-paulo-para-ir-com-criancas/. Accessed on June 20, 2019.

Burihan, S. Tamoios News, $16 \quad$ sep 2018 https://www.tamoiosnews.com.br/saneamento-basico/relatorio-mostra-que-olitoral-norte-tem-52-de-domicilios-com-coleta-de-esgoto/. Accessed on June $25,2019$.

${ }^{4}$ CETESB - Companhia Ambiental do Estado do São Paulo. Relatório de qualidade das praias no estado de São Paulo 2017. São Paulo: CETESB, 2017. http://praias.cetesb.sp.gov.br/publicacoes-relatorios/. Accessed on June 25, 2019.
} 